\title{
Interrelationships among yield and yield components in chickpea (Cicer arietinum L.) under irrigated and rainfed conditions
}

\author{
Soshma Jan ${ }^{1}$, Rozina Gul ${ }^{1}$, Fahim Ullah Khan ${ }^{1,2, *}$ Hamayun Khan $^{3}$ and \\ Sana Saeed ${ }^{1}$
}

1. Department of Plant Breeding \& Genetics, The University of Agriculture, Peshawar

2. Barani Agricultural Research Station, Kohat

3. Department of Agronomy, The University of Agriculture, Peshawar

*Corresponding author's email: fahimbiotech@gmail.com

Citation

Soshma Jan, Rozina Gul, Fahim Ullah Khan, Hamayun Khan and Sana Saeed. Interrelationships among yield and yield components in chickpea (Cicer arietinum $\mathrm{L}$.) under irrigated and rainfed conditions. Pure and Applied Biology. Vol. 4, Issue 4, 2015, pp 551-556. http://dx.doi.org/10.19045/bspab.2015.44014

\begin{tabular}{lll}
\hline \hline Received: 01/08/2015 & Revised: 05/11/2015 & Accepted: 14/11/2015 \\
\hline \hline
\end{tabular}

\section{Abstract}

Twenty chickpea genotypes were tested as independent experiments under rainfed and irrigated conditions during 2013-14 at The University of Agriculture Peshawar. Data was recorded on 16 metric traits viz. number of primary and secondary branches plant ${ }^{-1}$, pods plant $^{-1}$, seeds pod $^{-1}$, seed weight pod $^{-1}, 100$-grain weight, above ground biomass, seed yield and harvest index. The results of correlation analysis showed that seed yield plant $^{-1}$ had strong positive genotypic association with pods plant ${ }^{-1}$, seed weight pod $^{-1}, 100$ seed weight and biological yield under both production environments and high positive genotypic association with secondary branches plant ${ }^{-}$ ${ }^{1}$, seeds $\operatorname{pod}^{-1}$, biological yield and harvest index under irrigated condition only. Path coefficient analysis confirmed the true relationship of pods plant ${ }^{-1}$, seed weight pod $^{-1}$, under irrigated condition and seed weight pod $^{-1}$, harvest index and above ground biomass under rainfed condition. Hence, these characters could be used as selection criterion for further improvement in seed yield of chickpea.

Key words: Chickpea; Correlation; Path analysis; Selection criteria; Seed yield.

Introduction

Chickpea (Cicer arietinum L.) is the third most important pulse crop after pea and common bean in the world whereas; it ranks first in the Mediterranean region. In Khyber Pakhtunkhwa (Pakistan), about 75\% chickpea is grown on rainfed lands and its cultivation is concentrated in the southern districts of the province including Dera Ismail Khan, Tank, Lakki Marwat, Bannu and Karak [1]. Drought is a main problem in reducing the production of major cultivated crops. Although, chickpea survive well in low moisture environments but yet there are huge differences in performance of chickpea varieties grown under varied moisture stress conditions. Several attempts to assess the extent of suitability to drought condition using single factor have been made, but yet could not reach to the final conclusion due to variety of other factors and their interactive effect to drought tolerance [2].

Determination of correlation and path coefficients between yield and yield criteria 
is necessary for the selection of favorable plant types for effective chickpea breeding programs. Correlation coefficients in general show associations among independent characteristics and the degree of linear relation between these characteristics [3]. Path analysis helps to determine the direct and indirect effects of casual variables on the effect components. The main benefit of path analysis is that it allows the partitioning of correlation coefficients into its components [4]. The aim of this study was to determine interrelationship between subject variable to devise suitable selection criterion for further improvement in seed yield of chickpea.

\section{Materials and Methods}

The study pertaining to devising selection criteria in chickpea using correlation coefficients and path analysis, an experiment was conducted in the Department of Plant Breeding and Genetics, University of Agriculture, Peshawar during Rabi season of 2013-14. The experimental material comprised twenty elite chickpea genotypes viz; NKC-5-S16, NKC-5-S17, NKC-5-S21, NKC-5-S13, NKC-5-S15, NKC-5-S12, NKC-5-S20, NKC-5-S14, NDC-4-20-5, NDC-4-20-6, NDC-4-20-1, NDC-122, SL-329, SL-5-42, SL-8-14, Karak-1, Karak-2, Karak-3, ICC-19183 and NIFA-2005. The experimental material was sown in a trireplicate randomized complete block design (RCBD) under each tested environment. To avoid environmental biasness, both experiments were grown nearby in the same field, whereas the one treated as rainfed was not irrigated throughout the crop season. Each plot comprised of 4 rows measuring 4 meter and spaced 0.30 meter. The plant to plant and row to row distance was maintained at $10 \mathrm{~cm}$ and $30 \mathrm{~cm}$ respectively. Insecticide (Immamectin) was sprayed two times with 20 days interval for control of pod borer during pod formation phase. Manual weeding was done to keep the experiment weed free. Ten plants were selected at random from the central row of each plot for data recording on number of primary and secondary branches plant $^{-1}$, pods plant ${ }^{-1}$, seeds pod $^{-1}$, seed weight pod $^{-1}$, 100 grain weight, above ground biomass, seed yield and harvest index.

\section{Statistical analysis}

Genotypic correlations were computed by the procedure of [5]. Path coefficients were estimated according to $[4,6]$, where seed yield plant $^{-1}$ was taken as resultant variable and other contributing traits as causal variables.

\section{Results}

Genotypic correlation coefficients among important yield attributing traits of chickpea under irrigated and rainfed condition are given in Table 1. Correlation analysis depicted positive and significant relationships were found between seed yield plant $^{-1}$ and secondary branches plant ${ }^{-1}$ $\left(0.66^{* *}\right)$, pods plant $^{-1}(0.89 * *)$, seed weight $\operatorname{pod}^{-1}(0.42 *), 100$-seed weight $\left(0.51^{*}\right)$, biological yield $(0.83 * *)$ and harvest index $\left(0.64^{* *}\right)$ and non-significant association with number of seeds $\operatorname{pod}^{-1}(-0.35)$ under irrigated condition. Under rainfed condition, seed yield plant $^{-1}$ had significant positive association with pods plant ${ }^{-1}\left(0.67^{* *}\right)$, seed weight $\operatorname{pod}^{-1}(0.51 *), 100$-seed weight $(0.44 * *)$, and biological yield $(0.62 * *)$ while non-significant relationship with primary branches $(0.10)$, secondary branches $(0.06)$, seeds $\operatorname{pod}^{-1}(0.07)$ and harvest index (0.21).

Path coefficient analysis showing direct, indirect and total effects of yield components on seed yield plant ${ }^{-1}$ is given in Table 2 and 3 under irrigated and rainfed environment, respectively. Genotypic path coefficient analysis was carried out considering seed yield plant ${ }^{-1}$ as dependent variable and rest of the yield components as independent variables. The results pertaining to correlation revealed that seed yield plant ${ }^{-1}$ had highly significant genotypic relationship 
with pods plant ${ }^{-1}$ and biological yield under both production environments and with secondary branches plant ${ }^{-1}$ under irrigated condition only. Pod plant ${ }^{-1}$ had the greatest direct effect on seed yield plant ${ }^{-1}$ (1.12) and its indirect effects on seed yield were positive through secondary branches plant $^{-1}$ and 100-seed weight but negative through primary branches plant $^{-1}$, seed pod $^{-1}$, seed weight $\operatorname{pod}^{-1}$ and biological yield under irrigated system. The main reason for strong direct effect of pods plant ${ }^{-1}$ was due to strong positive correlation $\left(\mathrm{r}=0.89^{* *}\right)$ of this character with seed yield under irrigated system. Biological yield plant $^{-1}$ had the highest direct effect (0.67) on seed yield followed by harvest index (0.67) and seed weight $\operatorname{pod}^{-1}(0.34)$ and its positive indirect effects were observed through pods plant $^{-1}$, seeds $\operatorname{pod}^{-1}$, and seed weight pod $^{-1}$, under rainfed system. The second highest direct effect on seed yield was of seed weight pod $^{-1}$ (0.46) and its positive indirect contributions were through number of primary branches (0.01), secondary branches (0.01), seeds $\operatorname{pod}^{-1}(0.03)$ and 100-seed weight (0.02) under irrigated condition. This second direct effect of seed weight pod $^{-1}$ was due to moderate association (0.42) of this trait with seed yield plant ${ }^{-1}$ under irrigated condition.

Table 1. Genotypic association among various traits of 20 chickpea genotypes evaluated under irrigated (above diagonal) and rainfed (below diagonal) environments.

\begin{tabular}{|l|c|c|c|c|c|c|c|c|c|}
\hline Trait & PB & SB & PPL & SPP & SWPP & HSW & BY & SY & HI \\
\hline PB & -- & $0.40^{*}$ & $0.38^{\mathrm{NS}}$ & $-0.42^{*}$ & $-0.21^{\mathrm{NS}}$ & $0.39^{\mathrm{NS}}$ & $0.49^{*}$ & $0.25^{\mathrm{NS}}$ & $-0.44^{*}$ \\
\hline SB & $0.31^{\mathrm{NS}}$ & -- & $0.66^{* *}$ & $-0.48^{*}$ & $0.14^{\mathrm{NS}}$ & $0.51^{*}$ & $0.78^{* *}$ & $0.66^{* *}$ & $-0.21^{\mathrm{NS}}$ \\
\hline PPL & $0.15^{\mathrm{NS}}$ & $-0.11^{\mathrm{NS}}$ & -- & $-0.53^{*}$ & $-0.02^{\mathrm{NS}}$ & $0.44^{*}$ & $0.86^{* *}$ & $0.89^{* *}$ & $0.02^{\mathrm{NS}}$ \\
\hline SPP & $-0.47^{*}$ & $-0.25^{\mathrm{NS}}$ & $-0.52^{*}$ & -- & $0.21^{\mathrm{NS}}$ & $-0.82^{* *}$ & $-0.50^{*}$ & $-0.35^{\mathrm{NS}}$ & $0.20^{\mathrm{NS}}$ \\
\hline SWP & $-0.26^{\mathrm{NS}}$ & $0.16^{\mathrm{NS}}$ & $-0.28^{\mathrm{NS}}$ & $0.51^{*}$ & -- & $0.31^{\mathrm{NS}}$ & $0.14^{\mathrm{NS}}$ & $0.42^{*}$ & $0.40^{*}$ \\
\hline HSW & $0.33^{\mathrm{NS}}$ & $0.45^{*}$ & $0.28^{\mathrm{NS}}$ & $-0.68^{*} *$ & $0.26^{\mathrm{NS}}$ & -- & $0.55^{*}$ & $0.51^{*}$ & $-0.06^{\mathrm{NS}}$ \\
\hline BY & $0.13^{\mathrm{NS}}$ & $0.38^{\mathrm{NS}}$ & $0.50^{*}$ & $-0.42^{*}$ & $0.22^{\mathrm{NS}}$ & $0.64^{*} *$ & -- & $0.83^{* *}$ & $-0.35^{\mathrm{NS}}$ \\
\hline SY & $-0.10^{\mathrm{NS}}$ & $0.06^{\mathrm{NS}}$ & $0.67^{*}$ & $-0.07^{\mathrm{NS}}$ & $0.51^{*}$ & $0.44^{*}$ & $0.62^{* *}$ & -- & $0.21^{\mathrm{NS}}$ \\
\hline HI & $-0.22^{\mathrm{NS}}$ & $-0.26^{\mathrm{NS}}$ & $0.35^{\mathrm{NS}}$ & $0.31^{\mathrm{NS}}$ & $0.42^{*}$ & $-0.05^{\mathrm{NS}}$ & $-0.21^{\mathrm{NS}}$ & $0.64 * *$ & - \\
\hline
\end{tabular}

$*$ and $* *=$ Significant and highly significant at 5 and $1 \%$ probability, respectively. NS = Nonsignificant. 
Table 2. Path coefficient analysis showing direct, indirect and total effects of various traits with seed yield plant ${ }^{-1}$.

\begin{tabular}{|c|c|c|c|c|c|c|c|c|c|c|c|}
\hline \multirow{2}{*}{ Traits } & \multirow{2}{*}{ Direct effect } & \multicolumn{8}{|c|}{ Indirect effects } & \multirow{2}{*}{$\begin{array}{l}\text { Total } \\
\text { Indirect } \\
\text { effect }\end{array}$} & \multirow{2}{*}{$\begin{array}{l}\text { Total } \\
\text { effect }\end{array}$} \\
\hline & & PBR & SBR & PPL & SPP & SWPP & HSW & BY & HI & & \\
\hline PBR & $-0.03^{\mathrm{NS}}$ & --- & 0.02 & 0.44 & -0.06 & -0.10 & 0.04 & -0.12 & 0.05 & $0.28 *$ & $0.25^{\mathrm{NS}}$ \\
\hline SBR & $0.05^{\mathrm{NS}}$ & -0.01 & --- & 0.73 & -0.06 & 0.06 & 0.06 & -0.19 & 0.02 & $0.61 * *$ & $0.66 * *$ \\
\hline PPL & $1.12 * *$ & -0.01 & 0.03 & --- & -0.08 & -0.01 & 0.05 & -0.21 & 0.00 & $-0.23^{\mathrm{NS}}$ & $0.89 * *$ \\
\hline SPP & $0.13^{\mathrm{NS}}$ & 0.01 & -0.02 & -0.59 & --- & 0.11 & -0.10 & 0.12 & -0.02 & $-0.49 *$ & $\overline{-}-35^{\mathrm{NS}}$ \\
\hline SWPP & $0.46^{* *}$ & 0.01 & 0.01 & -0.02 & 0.03 & --- & 0.02 & -0.03 & -0.04 & $-0.04^{\mathrm{NS}}$ & $0.42 *$ \\
\hline HSW & $0.12^{\mathrm{NS}}$ & -0.01 & 0.02 & 0.50 & -0.11 & 0.14 & --- & -0.16 & 0.01 & $0.39 *$ & $0.51 *$ \\
\hline BY & $-0.24^{\mathrm{NS}}$ & -0.02 & 0.04 & 0.97 & -0.07 & 0.06 & 0.06 & --- & 0.02 & $1.07 * *$ & $0.83 * *$ \\
\hline HI & $-0.10^{\mathrm{NS}}$ & 0.01 & -0.01 & 0.02 & 0.03 & 0.18 & -0.01 & 0.08 & --- & $0.30 *$ & $0.21^{\mathrm{NS}}$ \\
\hline
\end{tabular}

Residual effect $=0.02$ and $\mathrm{R}^{2}=0.98$

$* * *=$ Significant at 5 and $1 \%$ probability, respectively whereas NS $=$ Non-significant

Table 3. Path coefficient analysis showing direct, indirect and total effects of various traits with seed yield plant ${ }^{-1}$.

\begin{tabular}{|c|c|c|c|c|c|c|c|c|c|c|c|}
\hline \multirow{2}{*}{ Traits } & \multirow{2}{*}{ Direct effect } & \multicolumn{8}{|c|}{ Indirect effects } & \multirow{2}{*}{$\begin{array}{l}\text { Total } \\
\text { Indirect } \\
\text { effect }\end{array}$} & \multirow{2}{*}{$\begin{array}{l}\text { Total } \\
\text { effect }\end{array}$} \\
\hline & & PB & SB & PPL & SPP & SWPP & HSW & BY & HI & & \\
\hline PB & $-0.04^{\mathrm{NS}}$ & -- & -0.01 & 0.02 & 0.14 & -0.09 & -0.08 & 0.09 & -0.14 & $-0.06^{\mathrm{NS}}$ & $\begin{array}{l}-0.10 \\
\text { NS }\end{array}$ \\
\hline B & $-0.02^{\mathrm{NS}}$ & -0.01 & --- & -0.01 & 0.07 & 0.05 & -0.10 & 0.26 & -0.18 & $0.08^{\mathrm{NS}}$ & $0.06^{\mathrm{NS}}$ \\
\hline PL & $0.13^{\mathrm{NS}}$ & -0.01 & 0.00 & --- & 0.14 & -0.10 & -0.07 & 0.33 & 0.24 & $0.54 * *$ & $0.67 * *$ \\
\hline SPP & $-0.27^{\mathrm{NS}}$ & 0.02 & & & --- & 0.17 & 0.16 & -0.29 & 0.21 & $0.20^{\mathrm{NS}}$ & \\
\hline SWPP & $0.34 *$ & 0.01 & 0.00 & -0.04 & -0.14 & --- & -0.06 & 0.14 & 0.26 & $0.17^{\mathrm{NS}}$ & $0.51 *$ \\
\hline HSW & $-0.23^{\mathrm{NS}}$ & -0.01 & -0.01 & 0.04 & 0.17 & 0.09 & --- & 0.43 & -0.03 & $0.67 * *$ & $0.44 *$ \\
\hline BY & $0.69 * *$ & 0.00 & -0.01 & 0.06 & 0.12 & 0.07 & -0.16 & --- & -0.15 & $-0.07^{\mathrm{NS}}$ & $0.62^{* *}$ \\
\hline HI & $0.67 * *$ & 0.01 & 0.00 & 0.05 & -0.08 & 0.13 & 0.01 & -0.15 & --- & $-0.03^{\mathrm{NS}}$ & $0.64 * *$ \\
\hline
\end{tabular}

Residual effect $=0.01$ and $\mathrm{R}^{2}=0.99$

$* * *=$ Significant at 5 and $1 \%$ probability, respectively whereas NS $=$ Non-significant

$\mathrm{PB}=$ Primary branches, $\mathrm{SB}=$ Secondary branches, $\mathrm{PPL}=\mathrm{Pods}_{\mathrm{plan}}{ }^{-1}, \mathrm{SPP}=\mathrm{Seeds} \operatorname{pod}^{-1}, \mathrm{SWPP}=$ Seed weight pod $^{-1}, \mathrm{HSW}=100$-seed weight, $\mathrm{BY}=$ Biological yield and HI= Harvest index. 


\section{Discussions}

For plant breeders, the magnitude of association of yield attributes with grain yield is of vital importance. Strong positive association of most of the traits studied suggested that improvement of seed yield in chickpea is linked with these traits and selection of these characters might have good impact on seed yield plant $^{-1}$. The results of the present study showed correlations among some characters were statistically significant but the path coefficient values were found non-significant for most of the traits which indicates the significance of path analysis over correlation analysis. According to these results; linear relationships among examined characters are insufficient in plant breeding programs. Previously, [3, 5-11] also reported significant positive relationship with yield attributes viz. primary branches plant $^{-1}$, secondary branches plant $^{-1}$, pods plant ${ }^{-1}$, seeds pod $^{-1}, 100$ seed weight, biological yield and harvest index. Similarly, [12, 13] reported that seed yield had significant positive relationship with branches, and with branches and pods plant ${ }^{-1}$ by [14], with seeds pod $^{-1}$ and harvest index by [15]. Conversely, significant negative association of seed yield was reported with 100 seed weight by [12], with secondary branches by [11], with seeds pod $^{-1}$ by [14], with branches plant ${ }^{-1}$ and 100 seed weight by [15].

The results pertaining to correlation revealed that seed yield plant $^{-1}$ had highly significant genotypic relationship with pods plant $^{-1}$ and biological yield under both production environments and with secondary branches plant $^{-1}$ under irrigated condition only. [3, 9, $11,15,16]$ also reported positive direct of harvest index, branches plant ${ }^{-1}$, pods plant ${ }^{-1}$, seeds pod $^{-1}$, seed weight pod $^{-1}, 100$ seed weight, and biological yield on seed yield in chickpea. This confirmed that pods plant ${ }^{-1}$ and seed weight pod $^{-1}$ under irrigated system and biological yield and harvest index under rainfed system, are direct contributors towards seed yield. Hence these traits could be explored more assertively as selection criteria for yield improvement in chickpea. In contrary, negative direct effect of 100 seed weight was reported by [15] and [11], whereas, negative direct effect of secondary branches on seed yield in chickpea by [3]. In contrary, negative direct effect of 100 seed weight was reported by [15] and [11], whereas, negative direct effect of secondary branches on seed yield in chickpea by [3, 17]. In conclusion, determining the linear relationships (correlations) among components affecting seed yield was insufficient to indicate selection criteria in chickpea breeding activities. Also it was essential that the levels of direct and indirect effects of the causal components (path analysis) were necessary to be determined.

\section{Authors' contributions}

Conceived and designed the experiments: $\mathrm{R}$ Gul. Performed the experiments: S Jan. Analyzed the data: F Khan. Contributed reagents/materials/analysis tools: $\mathrm{H}$ Khan \& S Saeed. Wrote the paper: F Khan \& S Jan.

\section{References}

1. Arshad M, Bakhsh A \& Ghafoor A (2004). Path coefficient analysis in chickpea (Cicer arietinum L.) under rainfed conditions. Pak J Bot 36(1): 7581.

2. Paramesh SG \& Salimath PM (2008). Field screening of chickpea genotypes for drought resistance. Karnataka J Agric Sci 21 (1): 113-114.

3. Ali MA, Nawab NN, Abbas A, Zulkiffal M \& Sajjad M (2009). Evaluation of selection criteria in Cicer arietinum L. using correlation coefficients and path analysis. Aust J Crop Sci 3(2):65-70.

4. Dewey DR \& Lu KH (1959). A correlation and path coefficient analysis of components of crested wheatgrass seed production. Agron J 51: 515-518.

5. Singh RK \& Chaudhery BD (1997). Biometrical methods in quantitative 
genetic analysis. Kalyani Pub. N. Delhi, India.

6. Zeeshan M, Arshad W, Ali S, Owais M, Zulkiffal M \& Hussain M (2013). Genetic divergence and character association in chickpea (Cicer arietinum L.) under rainfed conditions. Wudpecker J Agric. Res. 2(1): 28-32.

7. Malik SR, Bakhsh A, Asif MA, Iqbal U \& Iqbal SM (2010). Assessment of genetic variability and interrelationship among some agronomic traits in chickpea. Int'l $J$ Agric Biol 12: 81-85

8. Shamsi K, Kobraee S \& Haghparast R (2012). Drought stress mitigation using supplemental irrigation in rainfed chickpea (Cicer arietinum L.) varieties in Kermanshah, Iran. Afr J Biotech 9(27): 4197-4203.

9. Vaghela MD, Poshiya VK, Savaliya JJ, Davada BK \& Mungra KD (2009). Studies on character association and path analysis for seed yield and its components in chickpea (Cicer arietinum L.). Legume Res 32 (4): 245-249.

10. Qureshi AS, Shaukat A, Bakhsh A, Arshad M \& Ghafoor A (2004). An assessment of variability for economically important traits in chickpea (Cicer arietinum L.). Pak J Bot 36(4): 779-785.

11. Saleem M, Shehzad K, Javed M \& Rauf SA (2002). Heritability estimates for grain yield and quality characters in chickpea
(Cicer arietinum L.). Int'l J Agric Biol 4(2): 275-276.

12. Kanouni H, Khalily M \& Malhotra RS (2009). Assessment of cold tolerance of chickpea at rainfed highlands of Iran. AmEuras. J. Agric. Environ. Sci. 5 (2): 250254.

13. Ali MA, Nawab NN, Rasool G \& Saleem M (2008). Estimates of variability and correlations for quantitative traits in Cicer arietinum. J Agri Soc Sci 4: 177-79.

14. Bakhsh A, Arshad M \& Haqqani AM (2006). Effect of Genotype $\times$ Environment interaction on relationship between grain yield and its components in chickpea (Cicer arietinum L.). Pak J Bot 38(3):683-690.

15. Yucel DO \& Anlarsal AE (2010). Determination of selection criteria with path coefficient analysis in chickpea (Cicer arietinum L.) breeding. Bulg $J$ Agric Sci 16: 42-48.

16. Khan FU, Raziuddin \& Khalil IA (2013). Correlation and factorwise contribution of various traits related to yield in rapeseed (Brassica napus L.). American-Eurasian J. Agric. \& Environ. Sci., 13 (1): 101-104.

17. Gul R, Khan H, Khan NU \& Khan FU (2014). Characterization of chickpea germplasm for nodulation and effect of rhizobium inoculation on nodules number and seed yield. J Anim Plant Sci 24(5): 1421-1429. 